\title{
Association study and a systematic meta-analysis of the VNTR polymorphism in the 3'-UTR of dopamine transporter gene and attention-deficit hyperactivity disorder
}

\author{
Edna Grünblatt ${ }^{1,2,3,5}$ (D) Anna Maria Werling ${ }^{1} \cdot$ Alexander Roth $^{1} \cdot$ Marcel Romanos $^{4} \cdot$ Susanne Walitza $^{1,2,3}$
}

Received: 12 February 2019 / Accepted: 24 March 2019 / Published online: 28 March 2019

(c) The Author(s) 2019

\begin{abstract}
Attention-deficit hyperactivity disorder (ADHD) has been postulated to associate with dopaminergic dysfunction, including the dopamine transporter (DAT1). Several meta-analyses showed small but significant association between the 10-repeat allele in the DAT1 gene in 3'-untranslated region variant number tandem repeat polymorphism and child and adolescent ADHD, whereas in adult ADHD the 9-repeat allele was suggested to confer as risk allele. Interestingly, recent evidence indicated that the long-allele variants (10 repeats and longer) might confer to lower expression of the transporter in comparison to the short-allele. Therefore, we assessed here the association in samples consisting of families with child and adolescent ADHD as well as a case-control sample, using either the 10- versus 9-repeat or the long-versus short-allele approach. Following, we conducted a systematic review and meta-analysis, including family and case-control studies, using the two aforementioned approaches as well as stratifying to age and ethnicity. The first approach (10-repeat) resulted in nominal significant association in child and adolescent ADHD (OR $1.1050 p=0.0128$ ), that became significant stratifying to European population (OR $1.1301 p=0.0085$ ). The second approach (long-allele) resulted in significant association with the whole ADHD population (OR $1.1046 p=0.0048$ ), followed by significant association for child and adolescent ADHD (OR $1.1602 p=0.0006$ ) and in Caucasian and in European child and adolescent ADHD (OR $1.1310 p=0.0114$; OR $1.1661 p=0.0061$; respectively). We were not able to confirm the association reported in adults using both approaches. In conclusion, we found further indication for a possible DATl gene involvement; however, further studies should be conducted with stringent phenotyping to reduce heterogeneity, a limitation observed in most included studies.
\end{abstract}

Keywords Attention-deficit hyperactivity disorder $\cdot$ ADHD $\cdot$ Dopamine transporter $\cdot$ DAT1 $\cdot S L C 6 A 3 \cdot$ Meta-analysis

\section{Introduction}

Attention-deficit hyperactivity disorder (ADHD), characterized by persistent symptoms of inattention, hyperactivity and impulsivity, is one of the most common psychiatric and

Electronic supplementary material The online version of this article (https://doi.org/10.1007/s00702-019-01998-x) contains supplementary material, which is available to authorized users. behavioural disorders in children and adolescents, with more

Edna Grünblatt

edna.gruenblatt@kjpd.uzh.ch

1 Department of Child and Adolescent Psychiatry and Psychotherapy, University Hospital of Psychiatry Zurich, University of Zurich, Zurich, Switzerland

2 Neuroscience Center Zurich, University of Zurich and ETH Zurich, Zurich, Switzerland

3 Zurich Center for Integrative Human Physiology, University of Zurich, Zurich, Switzerland
4 Department of Child and Adolescent Psychiatry, Psychosomatics and Psychotherapy, Center of Mental Health, University Hospital of Wuerzburg, Würzburg, Germany

5 Translational Molecular Psychiatry, Department of Child and Adolescent Psychiatry and Psychotherapy, Centre for Child and Adolescent Psychiatry Research, University Hospital of Psychiatry Zurich, Wagistrasse 12, 8952 Schlieren, Switzerland 
than $5 \%$ of the paediatric population affected worldwide, and ADHD often persists into adulthood with a prevalence of 2.5-4.9\% in adults (Thomas et al. 2015; Polanczyk et al. 2014). ADHD has been shown to have a high genetic component with around $80 \%$ heritability (Faraone and Larsson 2018). A recent genome-wide association study of over 20,000 ADHD patients has identified 12 independent loci to be genome-wide significantly associated with ADHD (Demontis et al. 2019). Nevertheless, genetic variations such as variable number tandem repeats (VNTRs) cannot be captured on such arrays, and therefore, conventional gene association studies may provide further information. One of these VNTRs (rs28363170), located on the dopamine transporter gene (SLC6A3 / DATI) in the 3' untranslated region (UTR), with the 10- and 9-repeat alleles that are most common (Doucette-Stamm et al. 1995), were found to be associated with ADHD. In particular, the 10-repeat allele was described in several meta-analyses to associate with child and adolescent ADHD, though with a rather low effect size and in most cases with high heterogeneity between studies due to clinical phenotyping, age and ethnicity (Gizer et al. 2009; Yang et al. 2007). Nevertheless, further studies kept looking into the association between DAT1 gene and ADHD, also due to significant linkage findings with the chromosomal location $5 \mathrm{p} 13$ containing the gene and ADHD (Friedel et al. 2007). Since it is known that there are further variants (3-13-repeats) on the DAT1 3 '-UTR VNTR, expressing in various ethnicities in different frequencies (Mazei-Robinson and Blakely 2006), some studies looked also into associations with the 9- or the 11-repeat alleles. However, no association has been detected in child and adolescent ADHD both in European and Asian ethnicity (Li et al. 2006), whereas in adult ADHD a trend for association was found for 9-repeat allele carriers following a recent meta-analysis (Bonvicini et al. 2016).

The dopamine transporter is a key player in the dopaminergic system, regulating the synaptic dopamine homeostasis and its signalling. Since psychostimulants, such as amphetamine and methylphenidate, provide an effective treatment for ADHD (e.g., Faraone and Buitelaar 2010), are known to have high affinity to the transporter and inhibiting the transporter (Markowitz and Patrick 2008; Han and Gu 2006), the dopamine transporter has become one of the risk candidates for ADHD research. Dopamine controls numerous functions including attention, mood, cognition, reward and movement (Iversen and Iversen 2007). And altered dopamine homeostasis and particularly dopamine transporter is not exclusive for ADHD, but has been implicated in several disorders, including paediatric Bipolar Disorder (rs40184) (Mick et al. 2008), Major Depressive Disorder (9-repeat) (Lopez-Leon et al. 2008), Posttraumatic Stress Disorder (9-repeat) (Li et al. 2016), Tourette Syndrome (9-repeat associated with increased tics) (Tarnok et al. 2007),
Obsessive-Compulsive Disorder (9-repeat) (Taylor 2013), Alzheimer's disease (9-repeat) (Feher et al. 2014) and Alcoholism (9-repeat associated with alcohol withdrawal seizure and delirium tremens) (Du et al. 2011), while no association was found in Schizophrenia (Gamma et al. 2005)(see also meta-analysis in http://www.szgene.org) and Parkinson's disease (Geissler et al. 2017) [for detailed review on dopamine transporter and various CNS disorders see (McHugh and Buckley 2015)]. However most studies demonstrated either conflicting findings or having only a single finding lacking replications or having no significant findings. In a meta-analysis of a collection of naturalistic studies ADHD children without 10/10-repeat genotypes responded better to methylphenidate; however, this effect was not found in clinically monitored studies (Soleimani et al. 2018). On the other hand, Parkinson's disease carriers of the 9-repeat allele required lower levopoda doses, as well as were at risk of hallucination/psychosis following treatment (Politi et al. 2018). Similarly, in methamphetamine substance use, 9-repeat was shown to be a strong risk factor for a worse prognosis of methamphetamine psychosis (Ujike et al. 2003).

Investigation regarding the functional consequence of the aforementioned variants has shown some mixed results. In vitro, using various cell culture models and reporter gene designs, showed either the 9- or the 10-repeat to increase $D A T 1$ gene expression (Fuke et al. 2001; VanNess et al. 2005; Mill et al. 2005; Greenwood and Kelsoe 2003; InoueMurayama et al. 2002; Hill et al. 2010; Miller and Madras 2002). Ex vivo, gene expression in post-mortem brain as well as in periphery also showed some inconsistent results [3 monkey substantia nigra (SN) (Miller and Madras 2002], 20 post-mortem cerebellum and temporal lobe and 18 volunteers lymphocytes (Mill et al. 2002), 7 post-mortem midbrain (Brookes et al. 2007), post-mortem of 30 Alzheimer's disease $\mathrm{SN}$ and polar region of the frontal lobe (Pinsonneault et al. 2011), post-mortem of the ventral midbrain from 18 controls and 18 cocaine users (Zhou et al. 2014). To our knowledge, no data are available linking between central nervous system and blood DAT1 expression and DAT1 genotypes. However, Wiers et al. (2018) reported correlations in a small post-mortem study investigating DAT1 mRNA expression in SN of 3 adult ADHD and 13 controls and DAT protein expression in the Caudate. Indeed, they found a significant positive correlation between mRNA and protein expression in the two brain regions (Wiers et al. 2018). Furthermore, DNA methylation of the DATI cluster A in blood was significantly correlated with the DNA methylation of the DATl cluster A in SN (Wiers et al. 2018). In a recent meta-analysis of a collection of positron emission tomography (PET) a highly significant evidence for the 9-repeat allele was shown to be associated with increased dopamine-transporter activity in human adults, that was significant in healthy adults and only marginally significant 
in adult ADHD patients (Faraone et al. 2014). In the singlephoton emission computed tomography (SPECT) analysis, although containing small sample size, similar results were obtained for healthy adults, while for affected adults (ADHD, Parkinson's disease, Schizophrenia, and alcoholism) the opposite results were observed (Faraone et al. 2014). Interestingly, in adult age span (20-75 years of age) 10-repeat homozygotes showed reduced striatal activity during working memory task that reduced with age, that led to the hypothesis of earlier manifestation of cognitive impairment in 10-repeat homozygotes (Sambataro et al. 2015). Yet, most studies focused on the functional effects of the most frequent repeats, the 9- and 10-repeats, while few studies looked whether the other variants have any functional effect. In a recent study, the binding of HESR 1 and two transcription factors, known to bind at the VNTR-site of the DATI gene, was found to be inhibited depending on the length of the VNTR variant, with 11-repeats having low DATl expression compared to the short variants up to 6-repeats (Kanno and Ishiura 2011). Moreover, the non-coding RNA, miR-491 was found to inhibit $D A T 1$ expression in a dose-dependent manner, in which higher repeat number (11-repeats) inhibited the expression compared to low number of repeats (up to 1-repeat) (Jia et al. 2016).

Therefore, in the current case-control and family study, we assessed whether the association between DAT 3'-UTR VNTR 10-repeat carriers or long-allele (10-repeats and higher) carriers conveys a risk for ADHD. In addition, we conducted a systematic review of the literature followed by an updated meta-analysis, including all current available associations with DAT1 3'-UTR VNTR for case-control and family studies in child and adolescent as well as adult ADHD in various ethnicities. To address the possible confounding effects by age of patients, and their ethnicity, a stratified meta-analysis for each variable was conducted.

\section{Materials and methods}

\section{Study samples}

Two hundred and two Caucasian nuclear families (146 families with both parents and 56 families with 1 parent) were recruited and the index patients were investigated in the inand outpatient units and the day clinics of the Department of Child and Adolescent Psychiatry and Psychotherapy, University Hospital of Psychiatry Zurich. Families were included if at least the index patient fulfilled the diagnostic criteria for ADHD (F90.0 or F90.1) according to ICD-10 (World Health Organization 2016; Dilling et al. 1996). Accordingly, this resulted in total 738 individuals [202 index with ADHD $($ males $=153$, females $=49$ ); aged 12.62 \pm 3.05 ; IQ $102.7 \pm 13.2 ; 119$ parents and sibs with ADHD (males $=41$, females $=78$ ) and 417 control parents and sibs (males $=194$, females $=223$ )]. The ADHD diagnoses of the parents and siblings were reported by the parents. The clinical diagnostic assessment of the index patient was done by a child and adolescent psychiatrist or psychologist under supervision of a senior psychiatrist in the clinic. The index patient was required to be $\geq 6$ years old and to have an IQ over 75 as assessed with either the Wechsler Intelligence Scale for Children (WISC) (Wechsler 1991; Tewes et al. 1999), the Kaufman Assessment Battery for Children (K-ABC) (Kaufman and Kaufman 1983; Melchers and Preuss 1994), the Culture Fair Test (CFT-20-R) (Weiss 2006), Snijders-Oomen Nonverbal Intelligence Test (SON-R) (Tellegen et al. 2003) or Intelligence and Development Scales (IDS) (Grob et al. 2009). Exclusion criteria were (a) no Caucasian origin, (b) potentially confounding and severe psychiatric diagnoses such as psychosis, any pervasive developmental disorder, primary mood or anxiety disorder and Tourette's syndrome, (c) neurological disorders such as epilepsy, (d) a history of any acquired brain damage or evidence of the fetal alcohol syndrome, (e) premature deliveries (delivery before 37th gestational week) and/or (f) maternal reports of severe prenatal, perinatal or postnatal complications.

In the case-control setting, the 220 index patients $($ males $=164$, females $=56 ;$ aged $12.7 \pm 2.98 ;$ IQ $103.2 \pm 13.6)$ were compared to genetically independent 158 Caucasian healthy controls (males $=89$, females $=69$, aged 11.52 \pm 3.091 ; IQ $111.5 \pm 13.3$ ) who were recruited at the Departments of Child and Adolescent Psychiatry of the Universities of Wuerzburg and Zurich. The cases in the case-control study consist of some index from the family study with additional new cases without family members recruited. Informed written consent was obtained in all cases from the participants and their parents. The study was approved by the ethical commissions of both of the involved universities in accordance with the latest version of the Declaration of Helsinki, including an ethical permission granted by the Ethic Committees from Wuerzburg, and the Cantonal Ethic Committee of Zurich (Ref. Nr. KFO 140/03 and KEKZH-Nr. 2016-00101).

\section{Genotyping}

DNA was isolated either from whole blood collected in ethylenediaminetetraacetic acid (EDTA) tubes using QIAamp DNA Blood Maxi Kit (Qiagen), or from saliva collected in the Oragene DNA collection kit (DNA Genotek, Canada) and isolated as per manufacturer's protocol. DNA concentrations, A260/A280, and A260/A230 ratios were measured using a spectrophotometer (NanoVue Plus, GE). The study population was genotyped for the DAT1 3'-UTR VNTR polymorphism, using the primers F: 5'-TGTGGTGTAGGG AACGGCCTGAG-3' and R: 5'-CTTCCTGGAGGTCAC 
GGCTCAAGG-3'. A total volume of $25 \mu$ containing $1 \mu \mathrm{l}$ DNA sample $(50 \mathrm{ng} / \mu \mathrm{l})$ were mixed with $12.5 \mu$ l Promega GoTaq ${ }^{\circledR}$ Green Master Mix (Promega), $9.5 \mu \mathrm{l}$ water and $1 \mu \mathrm{l}$ of both primers (forward and reverse $10 \mu \mathrm{M}$ ). The reaction was performed in $0.2 \mathrm{ml}$ PCR 8-tube strips, sealed with individually attached caps (Bio-Rad) in a C1000 ${ }^{\mathrm{TM}} \mathrm{CFX} 96^{\mathrm{TM}}$ Thermal cycler (Bio-Rad). DNA amplification was achieved under the following conditions: $2 \mathrm{~min}$ at $95{ }^{\circ} \mathrm{C}$ followed by 30 cycles at $95{ }^{\circ} \mathrm{C}$ for $45 \mathrm{~s}, 67.5^{\circ} \mathrm{C}$ for $45 \mathrm{~s}, 72^{\circ} \mathrm{C}$ for $1 \mathrm{~min}$, and a final extension of $5 \mathrm{~min}$ at $72{ }^{\circ} \mathrm{C} .15 \mu \mathrm{l}$ of PCR product was loaded into a $3 \%$ agarose gel (SeaKem ${ }^{\circledR}$ LE Agarose mixed with 1x TAE buffer) stained with $5 \mu \mathrm{l}$ HDGreen ${ }^{\mathrm{TM}}$ Plus DNA Stain (Intas) per $100 \mathrm{~g}$ agarose and run for 90 min at 120 V. A $100 \mathrm{bp} \mathrm{BenchTop} \mathrm{DNA} \mathrm{ladder}$ (Promega) was used to assess the size of the PCR product and set the genotypes according to the expected bands of $316 \mathrm{bp}$ for 6-repeat allele, $396 \mathrm{bp}$ for 8-repeat allele, $436 \mathrm{bp}$ for 9-repeat allele, $476 \mathrm{bp}$ for 10-repeat allele and $516 \mathrm{bp}$ for 11-repeat allele. PCR were run for sample DNA samples in duplicates to ensure reproducibility. In case of ambiguity in the duplicates, genotyping was repeated in a separate run to resolve the discrepancy. No-template controls (NTC) were included in every run to exclude impurities.

\section{Statistical analysis}

All association studies were run on the PLINK v1.7 [URL: http://pngu.mgh.harvard.edu/purcell/plink/ (Purcell et al. 2007)]. Each study group (case-control study) was tested for Hardy-Weinberg equilibrium (HWE) that confirmed no deviations from HWE for all samples. For the case-control association study Fisher's Exact Test was conducted and significance was set at $p<0.025$ as Bonferroni correction was conducted (analysis of the DATl in two forms: long-allele vs. short-allele and 10-repeat vs. 9-repeat). For the family association study, Mendel errors test (none were found) followed by the transmission disequilibrium test (TDT) was conducted as well as a parent-of-origin analysis.

\section{Search strategy and study selection}

A systematic literature search was conducted to include studies that examined associations of DAT1 3'-UTR VNTR polymorphisms with ADHD. We searched PubMed and Web of Science databases for articles published until December 31, 2018. Literature was searched using the keywords: (DAT* OR SLC6A3 OR "dopamine transporter") AND (polymorphism* OR VNTR OR "tandem repeat" OR "untranslated region") AND (ADHD OR "attention hyperactivity"). As a further search manner, we searched the reference sections of the most recently published studies identified in literature search described above, as well as any recently published systematic review articles and meta-analysis, to identify studies that might have been missed. The Preferred Reporting Items for Systematic Reviews and MetaAnalyses (PRISMA) flow diagram (Liberati et al. 2009) was used to report the search flow for this meta-analysis. Studies included in our meta-analysis had to fulfil the following criteria: (1) detailed description of the sample size, ancestry of participants, and diagnostic criteria for ADHD, (2) case-control or family studies examining the association between DAT1 3'-UTR VNTR polymorphism and ADHD, and (3) containing data on allele/genotype frequencies in case and control groups and/or odds ratio (OR) and 95\% confidence interval (CI) for the OR, (4) samples not duplicative of other studies. In addition to performing a meta-analysis of all studies pooled together, we conducted a subgroup analysis by dividing the studies into those including patients with Caucasian or Asian ancestry to examine the effects of ethnic heterogeneity as well as for adult versus child and adolescent ADHD. If articles only reported allele/genotype frequencies, OR and 95\% CI was calculated from allele frequencies using an online OR calculator (https://www.genec alculators.net/associatorrr-cc.html). Corresponding authors and co-authors were contacted in case of missing data in the selected publications, and were asked to provide the missing information. In case of no respond, articles were excluded $(n=4)$.

\section{Data synthesis and statistical analysis}

The quality of all included studies was assessed based on traditional epidemiological considerations for genetic studies as previously described in Liu et al. (2015; Supplementary Table S1). The meta-analysis was conducted using the MIX 2.0-Professional software for meta-analysis in Excel, version 2.0.1.6 (http://www.meta-analysis-made-easy.com/) (Bax et al. 2006). The OR of each study was converted to the natural logarithm of OR [Ln (OR)], and 95\% CI to standard error (SE) using MIX 2.0 software. The Ln (OR), SE, and sample size $(N)$ were used in the software to perform heterogeneity statistics, heterogeneity funnel plots, and synthesis forest plots using inverse variance weighting. The heterogeneity between studies was assessed by Cochran's Chi square-based $Q$ statistic and the inconsistency index $\left(I^{2}\right)$, with $p<0.05$ being considered statistically significant. If there was significant $(p<0.05)$ heterogeneity between studies, we used the random-effects model, otherwise we used the fixed-effects model. The random-effects model considers both between-study and within-study variation, whereas the fixed-effects model considers only within-study variation (Borenstein et al. 2010). The heterogeneity $I^{2}$ are presented in Supplementary Tables S2 and S3. Potential publication bias was assessed using Begg's test (Begg and Mazumdar 1994) and Egger's regression test (Egger et al. 1997), with $p<0.05$ considered statistically significant (Supplementary 
Tables S2 and S3). In case of $p<0.05$ for publication bias, the trim and fill correction was conducted to explore the corrected OR and 95\% CI (Duval and Tweedie 2000).

\section{Results}

\section{DAT1 3'-UTR VNTR association with child and adolescent ADHD in the Zurich samples}

In the case-control study a nominal significant association between DAT1 3'-UTR VNTR long-allele and ADHD was observed (OR 0.697, 95\% CI 0.501-0.972, $p=0.03$ ). Furthermore, a significant association was found when assessing according to 10-repeat allele versus 9-repeat allele carriers (OR 0.676, 95\% CI 0.484-0.945, $p=0.024$ ). Test statistic was based on 211 cases and 155 controls, and genotypes are presented in Table 1a.

Family-based association analyses of the DAT1 3'-UTR VNTR long-allele as well as the 10-repeat versus 9-repeat allele yielded no significant association in the Zurich sample (OR 1.015, 95\% CI 0.726-1.418, $p=0.932$; OR 1.048, $95 \%$ CI $0.742-1.480, p=0.792$; respectively). Data from 46 heterozygous parents were included to assess the TDT, and genotypes are presented in Table $1 \mathrm{~b}$.

\section{Meta-analysis for DAT1 3'-UTR VNTR association with child, adolescent, and adult ADHD in different ethnical groups}

The literature search for studies reporting on the association of DAT1 3'-UTR VNTR with ADHD identified 899 non-duplicated articles (Supplementary Figure S1). Out of 861 articles, 767 articles were excluded at the title/abstract level. Altogether, 100 articles were read fully, and 34 articles were excluded because various reasons: e.g., missing data, overlapping samples in other publications or not fulfilling the inclusion criteria (Supplementary Table S4). Finally, 61 publications were included in the meta-analysis (Supplementary Table S5 including studies characteristics, demographics and quality assessment scores), including the current study results (Cook et al. 1995; Waldman et al. 1998; Jiang et al. 1999; Lunetta et al. 2000; Swanson et al. 2000; Curran et al. 2001; Todd et al. 2001; Maher et al. 2002; Smith et al. 2003; Carrasco et al. 2004; Kustanovich et al. 2004; Galili-Weisstub et al. 2005; Bakker et al. 2005; Bobb et al. 2005; Feng et al. 2005; Kim et al. 2005, 2006; Langley et al. 2005; Simsek et al. 2005; Hawi et al. 2005, 2010; Brookes et al. 2006; Cheuk et al. 2006; Hebebrand et al. 2006; Lim et al. 2006; Asherson et al. 2007; Brüggemann et al. 2007; Qian et al. 2007; Genro et al. 2008; Johansson et al. 2008; Wang et al. 2008; Banoei et al. 2008; Kopeckova et al. 2008; Franke et al. 2008, 2010; Niederhofer et al. 2008; Kereszturi et al. 2008; Gizer et al. 2009; Wohl et al. 2008; MartinezLevy et al. 2009, 2013; Dresler et al. 2010; Aparecida da Silva et al. 2011; Bidwell et al. 2011; Das et al. 2011; ElTarras et al. 2012; Hoogman et al. 2013; de Azeredo et al. 2014; Shang and Gau 2014; Hasler et al. 2015; Sery et al. 2015; Fonseca et al. 2015; Agudelo et al. 2015; GomezSanchez et al. 2016; Onnink et al. 2016; Ortega-Rojas et al. 2017; Stanley et al. 2017; Wiguna et al. 2017; Hong et al. 2018; Morgan et al. 2018). The summary of OR, SE, type of study (e.g., family TDT, case-control CC etc.), number of participants, age of cases (child and adolescent or adult ADHD), ethnicity/country, and the ID given for all studies included are presented in Supplementary Tables S6 and S7 (10-repeats vs. 9-repeats, and Long-allele vs. Short-allele, respectively). The meta-analyses summary of all DATI 3'-UTR VNTR analysis variations (long-allele vs. shortallele; 10-repeat vs. 9-repeat) with the entire publications,

Table 1 Genotype distribution of the DAT1 3'-UTR VNTR in both Zurich samples

(a) Case-control study sample

\begin{tabular}{lcccccc}
\hline & \multicolumn{2}{l}{ DAT1 3'-UTR VNTR genotypes } & & & \\
\cline { 2 - 6 } & $9 / 9$ & $10 / 9$ & $11 / 9$ & $10 / 10$ & $10 / 11$ & $11 / 11$ \\
\hline ADHD & 22 & 88 & 2 & 101 & 6 & 1 \\
Control & 9 & 54 & 1 & 90 & 2 & 0 \\
\hline
\end{tabular}

(b) Family study sample

\begin{tabular}{lllllll}
\hline \multicolumn{7}{c}{ DAT1 3'-UTR VNTR genotypes } \\
\cline { 2 - 6 } & $9 / 9$ & $10 / 9$ & $11 / 9$ & $10 / 10$ & $10 / 11$ \\
\hline ADHD & 19 & 82 & 1 & 94 & 5 & $11 / 11$ \\
Mother & 28 & 80 & 2 & 84 & 87 & 1 \\
Father & 8 & 53 & 1 & 93 & 2 & 1 \\
Sibs & 13 & 84 & 0 & & & 2 \\
\hline
\end{tabular}


(a) Forest plot for all ADHD studies ( $n=71$ )

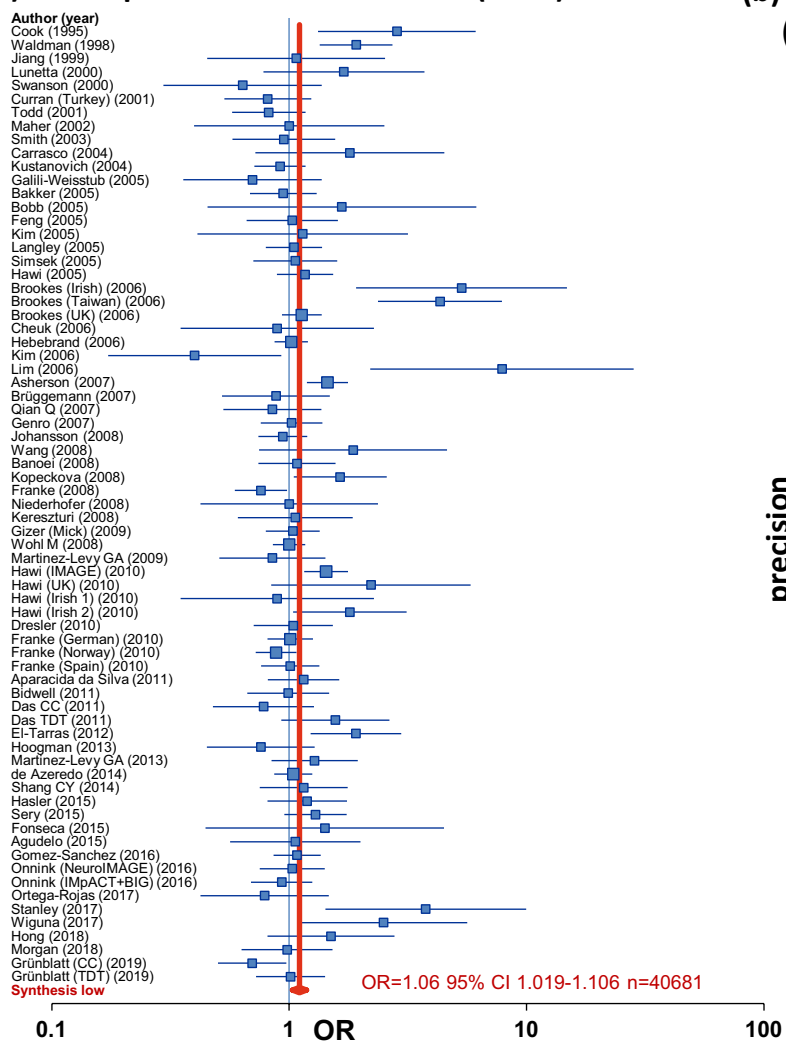

(c) Forest plot for all child and adolescent ADHD studies $(n=59)$

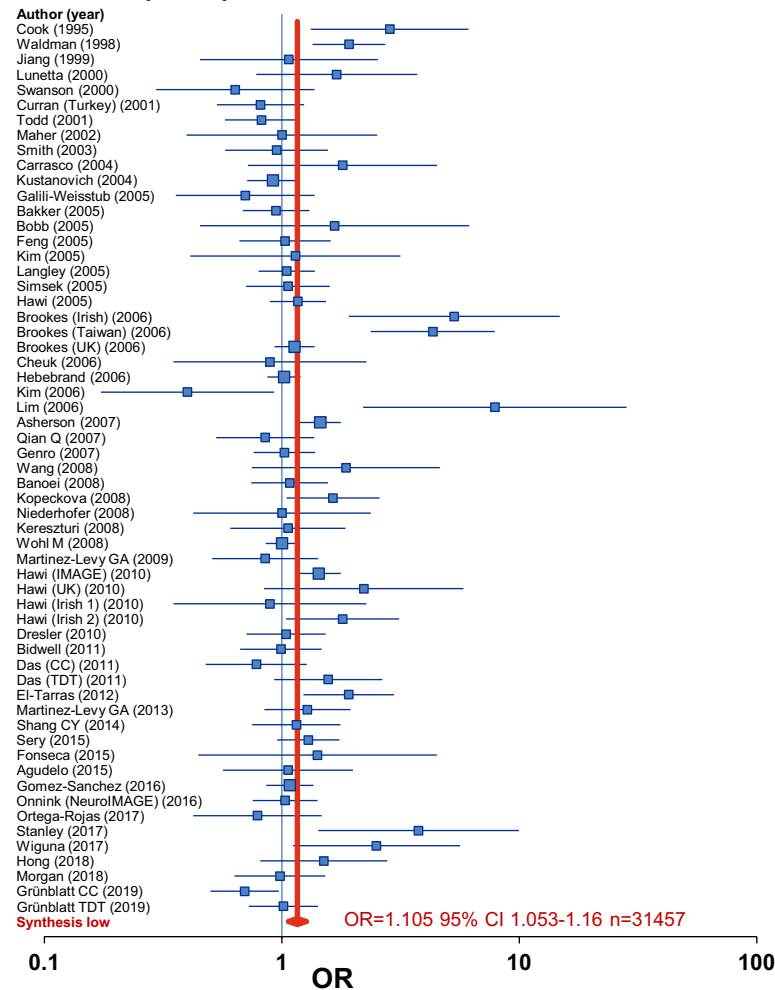

(b) Heterogeneity funnel plot for all ADHD studies $(n=71)$

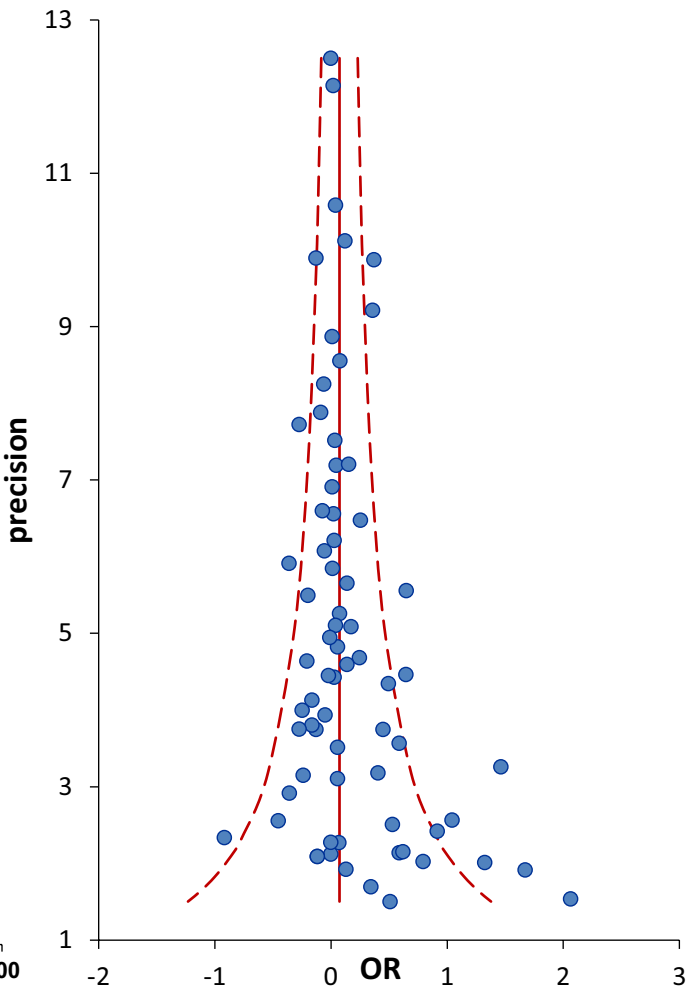

(d) Forest plot for all adult ADHD studies ( $n=12$ )

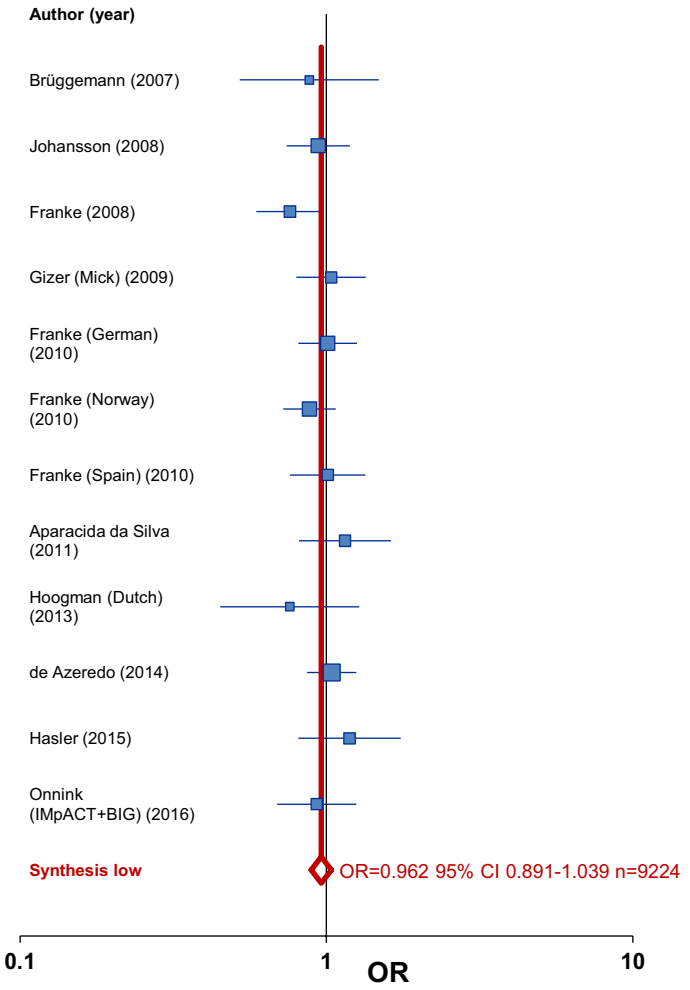


\Fig. 1 Meta-analysis of all cohorts and published association analyses $(n=71)$ of the DAT1 3'-UTR VNTR Long-allele with attentiondeficit hyperactivity disorder (ADHD) (a). Heterogeneity funnel plot assessing any evidence of publication bias for whole ADHD studies $I^{2}=54.167 \%(95 \%$ CI $40.03-64.97 \%) p=0(\mathbf{b})$. Forest plot in child and adolescent ADHD studies $(n=59)(\mathbf{c})$. Forest plot in adult ADHD studies $(n=12)(\mathbf{d})$. Black whiskers in the forest plot represent $95 \%$ confidence intervals (CI) for odds ratio; the weight (inverse variance) of the study is reflected in symbol (box) size. Sample demographics, individual statistics, heterogeneity, literature bias statistics, quality assessments and scores, and model used is summarized in Supplementary Tables S3, S5-S6. The order of the samples is as presented in the Supplementary Tables and in Supplementary Figures S2-S4, in a descending manner

stratified to age of cases (child and adolescent or adult ADHD) and ethnical grouping is presented in Supplementary Tables S2 and S3.

We found no significant association between 10-repeat allele carriers and the entire ADHD population, as well as after stratifying to adult ADHD (Supplementary Tables S2). However, stratification to child and adolescent ADHD resulted in a nominal significant association (OR 1.1050 95\% CI 1.0203-1.1968, $p=0.0128$ ), nevertheless the analysis was accompanied with high heterogeneity that was not due to publications bias. Following ethnical stratification, children and adolescent ADHD originating from Europe demonstrated a significant association with 10-repeat allele as risk allele (OR 1.1301 95\% CI 1.0316-1.2379, $p=0.0085$ ), nevertheless, also here a significant heterogeneity was found. For further detailed stratifications results see Supplementary Table S2.

DAT1 3'-UTR VNTR long-allele was significantly associated with ADHD assessed as the whole ADHD population (OR 1.1046 95\% CI 1.0309-1.1837, $p=0.0048$ ). Similarly to the 10-repeat analysis, significant heterogeneity was observed with publication bias. Following trim and fill correction the association was still significant with Longallele as risk allele (OR 1.0614 95\% CI 1.0186-1.1060). Following stratification with age, only child and adolescent ADHD kept the significant association (OR 1.1602 95\% CI 1.0657-1.2631, $p=0.0006$; Trim and Fill OR 1.1053 95\% CI 1.0525-1.1605), however still with high heterogeneity. In Caucasian child and adolescent ADHD, and in European child and adolescent ADHD, a significant association with the Long-allele was found (OR 1.1310 95\% CI 1.0282-1.2441, $p=0.0114$; OR $1.166195 \%$ CI $1.0448-1.3015, p=0.0061$; respectively). In the whole Asian population a nominal significant association was observed, however following trim and fill correction significance was lost (OR 1.0991 95\% CI 0.9240-1.3074). The forest and heterogeneity funnel plot for the whole ADHD sample is presented in Fig. 1a, b, and the forest plot results following stratification to age (child and adolescent-, adult-ADHD) is presented in Fig. 1c, d. Summary of the meta-analysis results for the ethnicity stratification is demonstrated in the world map in Fig. 2.

\section{Discussion}

The current meta-analysis, could confirm previous findings showing weak association between the 10-repeat allele of the DAT1 3'-UTR VNTR gene and child and adolescent ADHD, that reached significance only in the European population; however, this was accompanied by high heterogeneity that was in some cases due to literature bias but in other cases due to heterogeneity in clinical phenotyping, age or ethnicity (Li et al. 2006; Gizer et al. 2009). On the other hand, we were not able to confirm a significant association between the 9-repeat allele and adult ADHD as previously reported (Bonvicini et al. 2016), and only a nominal significant association was observed for the European adult ADHD with 9-repeat as risk allele (see Supplementary Table S2).

Interestingly, assessing the functional approach, in which the long-allele was suggested to result in decreased dopamine transporter expression (Faraone et al. 2014; Kanno and Ishiura 2011; Jia et al. 2016), seem to show significant association with ADHD. Indeed, the meta-analysis including the overall ADHD studies, as well as the child and adolescent ADHD, the Caucasian child and adolescent ADHD, the European child and adolescent ADHD, and nominally the Asian child and adolescent ADHD resulted in significant association with Long-allele as risk allele. In the other ethnical groups the associations did not reach significance, however all seem to show some tendency toward the long-allele as risk allele, however further studies should be conducted to confirm this hypothesis.

The current study included the largest sample size available (total $n=40,681$ consisting of 14,821 cases) for a powerful meta-analysis of the DAT1 3'-UTR VNTR gene variants, and used when needed the random-effects model that incorporate heterogeneity among trials (Borenstein et al. 2010). Indeed, following quality assessment of all included studies according to traditional epidemiological considerations (Liu et al. 2015) indicated that some studies did not reach high quality scores due to sample size, diagnostic criteria, recruitment strategies and quality control of the genetic analysis. This was reflected in significant heterogeneity, that in some cases, was also confirmed with significant publication bias assessed with Begg's test (Begg and Mazumdar 1994) and Egger's regression test (Egger et al. 1997). In these few cases we corrected the results using trim and fill correction (Duval and Tweedie 2000), that kept their significance even after correction.

To summarize the current study, we could show further evidence of the DATl 3'-UTR VNTR variants to play a role in ADHD, in particularly in child and adolescents with 


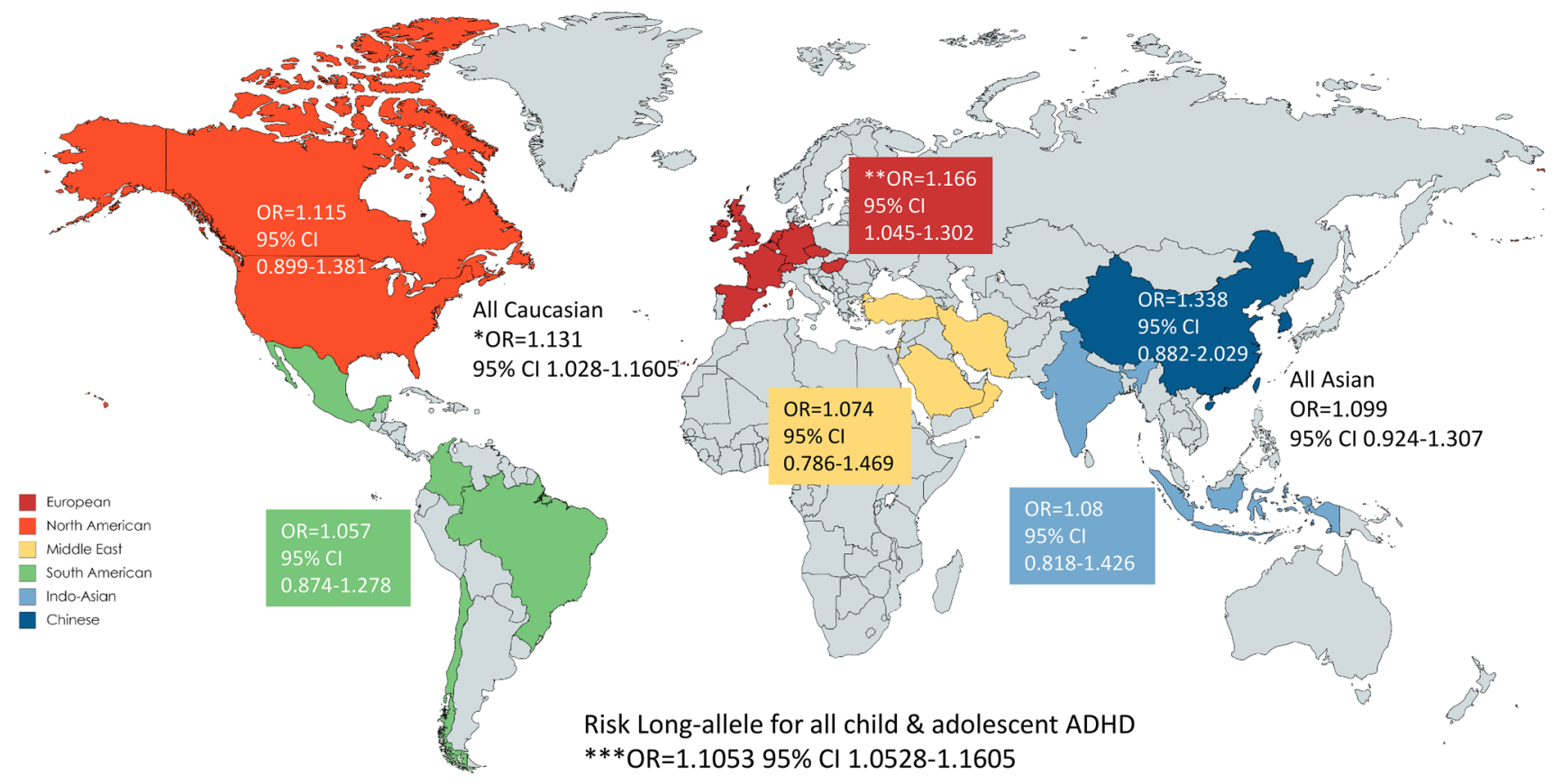

Fig. 2 World map overview of the countries that were included in the child and adolescent ADHD meta-analysis (DAT1 3'-UTR VNTR Long-repeat allele as risk allele) according to the various stratifica-

the Long-allele as risk allele. As previously hypothesized, this could indeed be due to the possible functional effect of the variants length in controlling the expression of the $D A T 1$ gene. However, as still high study heterogeneity was observed, with some studies not reaching high quality, further analysis is necessary to establish a robust conclusion.

Acknowledgements The authors thank the families, patients, and control volunteers who participated in this research. The authors would like to acknowledge Dr. Ian Gizer providing data from his meta-analysis from 2009, Dr. Susan Shur-Fen Gau, Dr. Chi-Yung Shang, Dr. Philip Asherson, Dr. Martine Hoogman, Dr. Marten Onnink, Dr. Mara Helena Hutz, Dr. Carlos S Cruz Fuentes, Dr. Gabriela Ariadna Martinez Levy, Dr. Kate Langley, Dr. Kanchan Mukhopadhyay, Mrs. Julia Morgan, Dr. Zsofia Nemoda, Dr. Jenny Ortega-Rojas, Dr. Ayusi Garcia Carmen and Dr. Clara Isabel Gomez Sanchez providing failing data of their publication and samples, Dr. Jie Li for translation of publications in Chinese into English, Ms. Rea Müller, Ms. Miryame Hofmann and Mrs. Susanne Kunert-Dümpelmann for their laboratory technical support. The authors acknowledge the Swiss National Science Foundation (Grant number SW 320030-130237) and the postdoctoral grant support for Anna Maria Werling by the University of Zurich, "Filling the Gap program".

Funding This project was supported by the Swiss National Science Foundation (Grant number SW 320030-130237) and the University of Zurich, "Filling the Gap program".

\section{Compliance with ethical standards}

Conflict of interest S. Walitza has received in the last 5 years royalities from Thieme Hogrefe, Kohlhammer, Springer, Beltz. S. Walitza has tions. The odds ratio (OR) and 95\% CI are displayed for each ethnicity category. $p$ value $<0.05^{*} ;<0.01 * * ;<0.001 * * *$

received lecture honoraria from Opopharma in the last 5 years. Her work was supported in the last 5 years by the Swiss National Science Foundation (SNF), diff. EU FP7s, HSM Hochspezialisierte Medizin of the Kanton Zurich, Switzerland, Bfarm Germany, ZInEP, Hartmann Müller Stiftung, Olga Mayenfisch, Gertrud Thalmann Fonds. Outside professional activities and interests are declared under the link of the University of Zurich http://www.uzh.ch/prof/ssl-dir/interessenbindu ngen/client/web/. The other authors declare no conflict of interest.

Open Access This article is distributed under the terms of the Creative Commons Attribution 4.0 International License (http://creativeco mmons.org/licenses/by/4.0/), which permits unrestricted use, distribution, and reproduction in any medium, provided you give appropriate credit to the original author(s) and the source, provide a link to the Creative Commons license, and indicate if changes were made.

\section{References}

Agudelo JA, Galvez JM, Fonseca DJ, Mateus HE, Talero-Gutierrez C, Velez-Van-Meerbeke A (2015) Evidence of an association between 10/10 genotype of DAT1 and endophenotypes of attention deficit/hyperactivity disorder. Neurologia 30(3):137-143

Aparecida da Silva M, Cordeiro Q, Louza M, Vallada H (2011) Lack of association between a 3'UTR VNTR polymorphism of dopamine transporter gene (SLC6A3) and ADHD in a Brazilian sample of adult patients. J Atten Disord 15(4):305-309. https://doi. org/10.1177/1087054710365989

Asherson P, Brookes K, Franke B, Chen W, Gill M, Ebstein RP, Buitelaar J, Banaschewski T, Sonuga-Barke E, Eisenberg J, Manor I, Miranda A, Oades RD, Roeyers H, Rothenberger A, Sergeant J, Steinhausen HC, Faraone SV (2007) Confirmation that a specific 
haplotype of the dopamine transporter gene is associated with combined-type ADHD. Am J Psychiatry 164(4):674-677. https ://doi.org/10.1176/ajp.2007.164.4.674

Bakker SC, van der Meulen EM, Oteman N, Schelleman H, Pearson PL, Buitelaar JK, Sinke RJ (2005) DAT1, DRD4, and DRD5 polymorphisms are not associated with ADHD in Dutch families. Am J Med Genet B 132B(1):50-52. https://doi.org/10.1002/ ajmg.b.30089

Banoei MM, Majidizadeh T, Shirazi E, Moghimi N, Ghadiri M, Najmabadi H, Ohadi M (2008) No association between the DAT1 10-repeat allele and ADHD in the Iranian population. Am J Med Genet B 147B(1):110-111. https://doi.org/10.1002/ ajmg.b.30578

Bax L, Yu LM, Ikeda N, Tsuruta H, Moons KG (2006) Development and validation of MIX: comprehensive free software for metaanalysis of causal research data. BMC Med Res Methodol 6:50. https://doi.org/10.1186/1471-2288-6-50

Begg CB, Mazumdar M (1994) Operating characteristics of a rank correlation test for publication bias. Biometrics 50(4):1088-1101

Bidwell LC, Willcutt EG, McQueen MB, DeFries JC, Olson RK, Smith SD, Pennington BF (2011) A family based association study of DRD4, DAT1, and 5HTT and continuous traits of attention-deficit hyperactivity disorder. Behav Genet 41(1):165-174. https:// doi.org/10.1007/s10519-010-9437-y

Bobb AJ, Addington AM, Sidransky E, Gornick MC, Lerch JP, Greenstein DK, Clasen LS, Sharp WS, Inoff-Germain G, WavrantDe Vrieze F, Arcos-Burgos M, Straub RE, Hardy JA, Castellanos FX, Rapoport JL (2005) Support for association between ADHD and two candidate genes: NET1 and DRD1. Am J Med Genet Part B Neuropsychiatr Genet 134b(1):67-72. https://doi. org/10.1002/ajmg.b.30142

Bonvicini C, Faraone SV, Scassellati C (2016) Attention-deficit hyperactivity disorder in adults: a systematic review and meta-analysis of genetic, pharmacogenetic and biochemical studies. Mol Psychiatry 21(7):872-884. https://doi.org/10.1038/mp.2016.74

Borenstein M, Hedges LV, Higgins JP, Rothstein HR (2010) A basic introduction to fixed-effect and random-effects models for meta-analysis. Res Synth Methods 1(2):97-111. https://doi. org/10.1002/jrsm.12

Brookes K, Xu X, Chen W, Zhou K, Neale B, Lowe N, Anney R, Franke B, Gill M, Ebstein R, Buitelaar J, Sham P, Campbell D, Knight J, Andreou P, Altink M, Arnold R, Boer F, Buschgens C, Butler L, Christiansen H, Feldman L, Fleischman K, Fliers E, Howe-Forbes R, Goldfarb A, Heise A, Gabriels I, Korn-Lubetzki I, Johansson L, Marco R, Medad S, Minderaa R, Mulas F, Muller U, Mulligan A, Rabin K, Rommelse N, Sethna V, Sorohan J, Uebel H, Psychogiou L, Weeks A, Barrett R, Craig I, Banaschewski T, Sonuga-Barke E, Eisenberg J, Kuntsi J, Manor I, McGuffin P, Miranda A, Oades RD, Plomin R, Roeyers H, Rothenberger A, Sergeant J, Steinhausen HC, Taylor E, Thompson M, Faraone SV, Asherson P (2006) The analysis of 51 genes in DSM-IV combined type attention deficit hyperactivity disorder: association signals in DRD4, DAT1 and 16 other genes. Mol Psychiatry 11(10):934-953. https://doi.org/10.1038/ sj.mp.4001869

Brookes KJ, Neale BM, Sugden K, Khan N, Asherson P, D'Souza UM (2007) Relationship between VNTR Polymorphisms of the human dopamine transporter gene and expression in post-mortem midbrain tissue. Am J Med Genet B 144B(8):1070-1078. https ://doi.org/10.1002/ajmg.b.30572

Brüggemann D, Sobanski E, Alm B, Schubert T, Schmalzried H, Philipsen A, Breen G, Becker T, Georgi A, Skowronek MH, Schulze TG, Treutlein J, Rietschel M (2007) No association between a common haplotype of the 6 and 10-repeat alleles in intron 8 and the $3^{\prime} \mathrm{UTR}$ of the DAT1 gene and adult attention deficit hyperactivity disorder. Psychiatr Genet 17(2):121. https ://doi.org/10.1097/YPG.0b013e32801231d4

Carrasco X, Rothhammer P, Moraga M, Henriquez H, Aboitiz F, Rothhammer F (2004) Presence of DRD4/7R and DAT1/10R allele in Chilean family members with attention deficit hyperactivity disorder. Rev Medica Chile 132(9):1047-1052

Cheuk DK, Li SY, Wong V (2006) No association between VNTR polymorphisms of dopamine transporter gene and attention deficit hyperactivity disorder in Chinese children. Am J Med Genet Part B Neuropsychiatr Genet 141b(2):123-125. https:// doi.org/10.1002/ajmg.b.30280

Cook EH, Stein MA, Krasowski MD, Cox NJ, Olkon DM, Kieffer JE, Leventhal BL (1995) Association of attention-deficit disorder and the dopamine transporter gene. Am J Hum Genet 56(4):993-998

Curran S, Mill J, Tahir E, Kent L, Richards S, Gould A, Huckett L, Sharp J, Batten C, Fernando S, Ozbay F, Yazgan Y, Simonoff E, Thompson M, Taylor E, Asherson P (2001) Association study of a dopamine transporter polymorphism and attention deficit hyperactivity disorder in UK and Turkish samples. Mol Psychiatry 6(4):425-428. https://doi.org/10.1038/sj.mp.40009 14

Das M, Das Bhowmik A, Bhaduri N, Sarkar K, Ghosh P, Sinha S, Ray A, Chatterjee A, Mukhopadhyay K (2011) Role of gene-gene/ gene-environment interaction in the etiology of eastern Indian ADHD probands. Prog Neuro-Psychopharmacol Biol Psychiatry 35(2):577-587. https://doi.org/10.1016/j.pnpbp.2010.12.027

de Azeredo LA, Rovaris DL, Mota NR, Polina ER, Marques FZ, Contini V, Vitola ES, Belmonte-de-Abreu P, Rohde LA, Grevet EH, Bau CH (2014) Further evidence for the association between a polymorphism in the promoter region of SLC6A3/DAT1 and ADHD: findings from a sample of adults. Eur Arch Psychiatry Clin Neurosci 264(5):401-408. https://doi.org/10.1007/s0040 6-014-0486-8

Demontis D, Walters RK, Martin J, Mattheisen M, Als TD, Agerbo E, Baldursson G, Belliveau R, Bybjerg-Grauholm J, BaekvadHansen M, Cerrato F, Chambert K, Churchhouse C, Dumont A, Eriksson N, Gandal M, Goldstein JI, Grasby KL, Grove J, Gudmundsson OO, Hansen CS, Hauberg ME, Hollegaard MV, Howrigan DP, Huang H, Maller JB, Martin AR, Martin NG, Moran J, Pallesen J, Palmer DS, Pedersen CB, Pedersen MG, Poterba T, Poulsen JB, Ripke S, Robinson EB, Satterstrom FK, Stefansson H, Stevens C, Turley P, Walters GB, Won H, Wright MJ, Consortium AWGotPG, Early L, Genetic Epidemiology C, andMe Research T, Andreassen OA, Asherson P, Burton CL, Boomsma DI, Cormand B, Dalsgaard S, Franke B, Gelernter J, Geschwind D, Hakonarson H, Haavik J, Kranzler HR, Kuntsi J, Langley K, Lesch KP, Middeldorp C, Reif A, Rohde LA, Roussos P, Schachar R, Sklar P, Sonuga-Barke EJS, Sullivan PF, Thapar A, Tung JY, Waldman ID, Medland SE, Stefansson K, Nordentoft M, Hougaard DM, Werge T, Mors O, Mortensen PB, Daly MJ, Faraone SV, Borglum AD, Neale BM (2019) Discovery of the first genome-wide significant risk loci for attention deficit/hyperactivity disorder. Nat Genet 51(1):63-75. https://doi. org/10.1038/s41588-018-0269-7

Dilling H, Freyberger HJ, Stieglitz RD (1996) ICD-10 field trial of the diagnostic criteria for research in German-speaking countries. Introd Psychopathol 29(5):258-259

Doucette-Stamm LA, Blakely DJ, Tian J, Mockus S, Mao JI (1995) Population genetic study of the human dopamine transporter gene (DAT1). Genet Epidemiol 12(3):303-308. https://doi. org/10.1002/gepi.1370120307

Dresler T, Ehlis AC, Heinzel S, Renner TJ, Reif A, Baehne CG, Heine M, Boreatti-Hummer A, Jacob CP, Lesch KP, Fallgatter AJ (2010) Dopamine transporter (SLC6A3) genotype impacts neurophysiological correlates of cognitive response control in an 
adult sample of patients with ADHD. Neuropsychopharmacology 35(11):2193-2202. https://doi.org/10.1038/npp.2010.91

Du Y, Nie Y, Li Y, Wan YJ (2011) The association between the SLC6A3 VNTR 9-repeat allele and alcoholism-a meta-analysis. Alcohol Clin Exp Res 35(9):1625-1634. https://doi.org/10.111 1/j.1530-0277.2011.01509.x

Duval S, Tweedie R (2000) Trim and fill: a simple funnel-plot-based method of testing and adjusting for publication bias in metaanalysis. Biometrics 56(2):455-463

Egger M, Davey Smith G, Schneider M, Minder C (1997) Bias in meta-analysis detected by a simple, graphical test. BMJ 315(7109):629-634

El-Tarras AE, Alsulaimani AA, Awad NS, Mitwaly N, Said MM, Sabry AM (2012) Association study between the dopaminerelated candidate gene polymorphisms and ADHD among Saudi Arabia population via PCR technique. Mol Biol Rep 39(12):11081-11086. https://doi.org/10.1007/s1103 3-012-2012-2

Faraone SV, Buitelaar J (2010) Comparing the efficacy of stimulants for ADHD in children and adolescents using meta-analysis. Eur Child Adolesc Psychiatry 19(4):353-364. https://doi. org/10.1007/s00787-009-0054-3

Faraone SV, Larsson H (2018) Genetics of attention deficit hyperactivity disorder. Mol Psychiatry. https://doi.org/10.1038/s4138 0-018-0070-0

Faraone SV, Spencer TJ, Madras BK, Zhang-James Y, Biederman J (2014) Functional effects of dopamine transporter gene genotypes on in vivo dopamine transporter functioning: a meta-analysis. Mol Psychiatry 19(8):880-889. https://doi.org/10.1038/ mp.2013.126

Feher A, Juhasz A, Pakaski M, Kalman J, Janka Z (2014) Association between the 9 repeat allele of the dopamine transporter $40 \mathrm{bp}$ variable tandem repeat polymorphism and Alzheimer's disease. Psychiatry Res 220(1-2):730-731. https://doi.org/10.1016/j. psychres.2014.07.060

Feng Y, Wigg KG, Makkar R, Ickowicz A, Pathare T, Tannock R, Roberts W, Malone M, Kennedy JL, Schachar R, Barr CL (2005) Sequence variation in the 3'-untranslated region of the dopamine transporter gene and attention-deficit hyperactivity disorder (ADHD). Am J Med Genet B 139B(1):1-6. https://doi. org/10.1002/ajmg.b30190

Fonseca DJ, Mateus HE, Galvez JM, Forero DA, Talero-Gutierrez C, Velez-van-Meerbeke A (2015) Lack of association of polymorphisms in six candidate genes in colombian adhd patients. Ann Neurosci 22(4):217-221. https://doi.org/10.5214/ ans.0972.7531.220405

Franke B, Hoogman M, Arias Vasquez A, Heister JG, Savelkoul PJ, Naber M, Scheffer H, Kiemeney LA, Kan CC, Kooij JJ, Buitelaar JK (2008) Association of the dopamine transporter (SLC6A3/ DAT1) gene 9-6 haplotype with adult ADHD. Am J Med Genet Part B Neuropsychiatr Genet 147b(8):1576-1579. https://doi. org/10.1002/ajmg.b.30861

Franke B, Vasquez AA, Johansson S, Hoogman M, Romanos J, Boreatti-Hummer A, Heine M, Jacob CP, Lesch KP, Casas M, Ribases M, Bosch R, Sanchez-Mora C, Gomez-Barros N, FernandezCastillo N, Bayes M, Halmoy A, Halleland H, Landaas ET, Fasmer OB, Knappskog PM, Heister A, Kiemeney LA, Kooij JJS, Boonstra AM, Kan CC, Asherson P, Faraone SV, Buitelaar JK, Haavik J, Cormand B, Ramos-Quiroga JA, Reif A (2010) Multicenter analysis of the SLC6A3/DAT1 VNTR haplotype in persistent ADHD suggests differential involvement of the gene in childhood and persistent ADHD. Neuropsychopharmacology 35(3):656-664. https://doi.org/10.1038/npp.2009.170

Friedel S, Saar K, Sauer S, Dempfle A, Walitza S, Renner T, Romanos M, Freitag C, Seitz C, Palmason H, Scherag A, Windemuth-Kieselbach C, Schimmelmann BG, Wewetzer C, Meyer
J, Warnke A, Lesch KP, Reinhardt R, Herpertz-Dahlmann B, Linder M, Hinney A, Remschmidt H, Schafer H, Konrad K, Hubner N, Hebebrand J (2007) Association and linkage of allelic variants of the dopamine transporter gene in ADHD. Mol Psychiatry 12(10):923-933. https://doi.org/10.1038/sj.mp.4001986

Fuke S, Suo S, Takahashi N, Koike H, Sasagawa N, Ishiura S (2001) The VNTR polymorphism of the human dopamine transporter (DAT1) gene affects gene expression. Pharmacogenomics J 1(2):152-156

Galili-Weisstub E, Levy S, Frisch A, Gross-Tsur V, Michaelovsky E, Kosov A, Meltzer A, Goltser T, Serretti A, Cusin C, Darvasi A, Inbar E, Weizman A, Segman RH (2005) Dopamine transporter haplotype and attention-deficit hyperactivity disorder. Mol Psychiatry 10(7):617-618. https://doi.org/10.1038/sj.mp.4001655

Gamma F, Faraone SV, Glatt SJ, Yeh YC, Tsuang MT (2005) Metaanalysis shows schizophrenia is not associated with the 40-basepair repeat polymorphism of the dopamine transporter gene. Schizophr Res 73(1):55-58. https://doi.org/10.1016/j.schre s.2004.09.020

Geissler JM, International Parkinson Disease Genomics Consortium M, Romanos M, Gerlach M, Berg D, Schulte C (2017) No genetic association between attention-deficit/hyperactivity disorder (ADHD) and Parkinson's disease in nine ADHD candidate SNPs. Attent Deficit Hyperact Disord 9(2):121-127. https://doi. org/10.1007/s12402-017-0219-8

Genro JP, Polanczyk GV, Zeni C, Oliveira AS, Roman T, Rohde LA, Hutz MH (2008) A common haplotype at the dopamine transporter gene $5^{\prime}$ region is associated with attention-deficit/hyperactivity disorder. Am J Med Genet B 147B(8):1568-1575. https ://doi.org/10.1002/ajmg.b.30863

Gizer IR, Ficks C, Waldman ID (2009) Candidate gene studies of ADHD: a meta-analytic review. Hum Genet 126(1):51-90. https ://doi.org/10.1007/s00439-009-0694-x

Gomez-Sanchez CI, Riveiro-Alvarez R, Soto-Insuga V, Rodrigo M, Tirado-Requero P, Mahillo-Fernandez I, Abad-Santos F, Carballo JJ, Dal-Re R, Ayuso C (2016) Attention deficit hyperactivity disorder: genetic association study in a cohort of Spanish children. Behav Brain Funct 12:10. https://doi.org/10.1186/s1299 3-015-0084-6

Greenwood TA, Kelsoe JR (2003) Promoter and intronic variants affect the transcriptional regulation of the human dopamine transporter gene. Genomics 82(5):511-520

Grob A, Meyer C, Hagmann-von Arx P (2009) Intelligence and development scales (IDS). Intelligenz- und Entwicklungsskalen für Kinder von 5-10 Jahren. Verlag Hans Huber, Bern

Han DD, Gu HH (2006) Comparison of the monoamine transporters from human and mouse in their sensitivities to psychostimulant drugs. BMC Pharmacol 6:6. https://doi. org/10.1186/1471-2210-6-6

Hasler R, Salzmann A, Bolzan T, Zimmermann J, Baud P, Giannakopoulos P, Perroud N (2015) DAT1 and DRD4 genes involved in key dimensions of adult ADHD. Neurol Sci 36(6):861-869. https ://doi.org/10.1007/s10072-014-2051-7

Hawi Z, Segurado R, Conroy J, Sheehan K, Lowe N, Kirley A, Shields D, Fitzgerald M, Gallagher L, Gill M (2005) Preferential transmission of paternal alleles at risk genes in attention-deficit/hyperactivity disorder. Am J Hum Genet 77(6):958-965. https://doi. org/10.1086/498174

Hawi Z, Kent L, Hill M, Anney RJ, Brookes KJ, Barry E, Franke B, Banaschewski T, Buitelaar J, Ebstein R, Miranda A, Oades RD, Roeyers H, Rothenberger A, Sergeant J, Sonuga-Barke E, Steinhausen HC, Faraone SV, Asherson P, Gill M (2010) ADHD and DAT1: further evidence of paternal over-transmission of risk alleles and haplotype. Am J Med Genet Part B Neuropsychiatr Genet 153b(1):97-102. https://doi.org/10.1002/ajmg.b.30960 
Hebebrand J, Dempfle A, Saar K, Thiele H, Herpertz-Dahlmann B, Linder M, Kiefl H, Remschmidt H, Hemminger U, Warnke A, Knolker U, Heiser P, Friedel S, Hinney A, Schafer H, Nurnberg P, Konrad K (2006) A genome-wide scan for attention-deficit/ hyperactivity disorder in 155 German sib-pairs. Mol Psychiatry 11(2):196-205. https://doi.org/10.1038/sj.mp.4001761

Hill M, Anney RJ, Gill M, Hawi Z (2010) Functional analysis of intron 8 and $3^{\prime}$ UTR variable number of tandem repeats of SLC6A3: differential activity of intron 8 variants. Pharmacogenomics $\mathbf{J}$ 10(5):442-447. https://doi.org/10.1038/tpj.2009.66

Hong JH, Hwang IW, Lim MH, Kwon HJ, Jin HJ (2018) Genetic associations between ADHD and dopaminergic genes (DAT1 and DRD4) VNTRs in Korean children. Genes Genom 40(12):13091317. https://doi.org/10.1007/s13258-018-0726-9

Hoogman M, Onnink M, Cools R, Aarts E, Kan C, Arias Vasquez A, Buitelaar J, Franke B (2013) The dopamine transporter haplotype and reward-related striatal responses in adult ADHD. Eur Neuropsychopharmacol J Eur Coll Neuropsychopharmacol 23(6):469-478. https://doi.org/10.1016/j.euroneuro.2012.05.011

Inoue-Murayama M, Adachi S, Mishima N, Mitani $\mathrm{H}$, Takenaka O, Terao K, Hayasaka I, Ito S, Murayama Y (2002) Variation of variable number of tandem repeat sequences in the 3'-untranslated region of primate dopamine transporter genes that affects reporter gene expression. Neurosci Lett 334(3):206-210

Iversen SD, Iversen LL (2007) Dopamine: 50 years in perspective. Trends Neurosci 30(5):188-193. https://doi.org/10.1016/j. tins.2007.03.002

Jia X, Wang F, Han Y, Geng X, Li M, Shi Y, Lu L, Chen Y (2016) miR-137 and miR-491 negatively regulate dopamine transporter expression and function in neural cells. Neurosci Bull 32(6):512522. https://doi.org/10.1007/s12264-016-0061-6

Jiang S, Xin R, Qian Y, Lin S, Tang G, Wang D, Chen M, Ren D (1999) The relationship between attention-deficit hyperactivity disorder and dopamine transporter 1 gene. Chin J Nerv Ment Dis 25:355-357

Johansson S, Halleland H, Halmoy A, Jacobsen KK, Landaas ET, Dramsdahl M, Fasmer OB, Bergsholm P, Lundervold AJ, Gillberg C, Hugdahl K, Knappskog PM, Haavik J (2008) Genetic analyses of dopamine related genes in adult ADHD patients suggest an association with the DRD5-microsatellite repeat, but not with DRD4 or SLC6A3 VNTRs. Am J Med Genet B 147B(8):1470-1475. https://doi.org/10.1002/ajmg.b.30662

Kanno K, Ishiura S (2011) Differential effects of the HESR/HEY transcription factor family on dopamine transporter reporter gene expression via variable number of tandem repeats. J Neurosci Res 89(4):562-575. https://doi.org/10.1002/jnr.22593

Kaufman A, Kaufman N (1983) K-ABC: Kaufman-assessment battery for children. American Guidance Service, Circle Pines

Kereszturi E, Tarnok Z, Bognar E, Lakatos K, Farkas L, Gadoros J, Sasvari-Szekely M, Nemoda Z (2008) Catechol- $O$-methyltransferase Val158Met polymorphism is associated with methylphenidate response in ADHD children. Am J Med Genet B 147B(8):1431-1435. https://doi.org/10.1002/ajmg.b.30704

Kim YS, Leventhal BL, Kim SJ, Kim BN, Cheon KA, Yoo HJ, Kim SJ, Badner J, Cook EH (2005) Family-based association study of DAT1 and DRD4 polymorphism in Korean children with ADHD. Neurosci Lett 390(3):176-181. https://doi.org/10.1016/j.neule t.2005.08.025

Kim JW, Kim BN, Cho SC (2006) The dopamine transporter gene and the impulsivity phenotype in attention deficit hyperactivity disorder: a case-control association study in a Korean sample. J Psychiatry Res 40(8):730-737. https://doi.org/10.1016/j.jpsyc hires.2005.11.002

Kopeckova M, Paclt I, Petrasek J, Pacltova D, Malikova M, Zagatova V (2008) Some ADHD polymorphisms (in genes DAT1, DRD2,
DRD3, DBH, 5-HTT) in case-control study of 100 subjects 6-10 age. Neuroendocrinol Lett 29(2):246-251

Kustanovich V, Ishii J, Crawford L, Yang M, McGough JJ, McCracken JT, Smalley SL, Nelson SF (2004) Transmission disequilibrium testing of dopamine-related candidate gene polymorphisms in ADHD: confirmation of association of ADHD with DRD4 and DRD5. Mol Psychiatry 9(7):711-717. https://doi.org/10.1038/ sj.mp.4001466

Langley K, Turic D, Peirce TR, Mills S, Van den Bree MB, Owen MJ, O'Donovan MC, Thapar A (2005) No support for association between the dopamine transporter (DAT1) gene and ADHD. Am J Med Genet B 139B(1):7-10. https://doi. org/10.1002/ajmg.b.30206

Li D, Sham PC, Owen MJ, He L (2006) Meta-analysis shows significant association between dopamine system genes and attention deficit hyperactivity disorder (ADHD). Hum Mol Genet 15(14):2276-2284. https://doi.org/10.1093/hmg/ddl152

Li L, Bao Y, He S, Wang G, Guan Y, Ma D, Wang P, Huang X, Tao S, Zhang D, Liu Q, Wang Y, Yang J (2016) The association between genetic variants in the dopaminergic system and posttraumatic stress disorder: a meta-analysis. Medicine (Baltimore) 95(11):e3074. https://doi.org/10.1097/MD.00000 00000003074

Liberati A, Altman DG, Tetzlaff J, Mulrow C, Gotzsche PC, Ioannidis JP, Clarke M, Devereaux PJ, Kleijnen J, Moher D (2009) The PRISMA statement for reporting systematic reviews and meta-analyses of studies that evaluate health care interventions: explanation and elaboration. PLoS Med 6(7):e1000100. https:// doi.org/10.1371/journal.pmed.1000100

Lim MH, Kim HW, Paik KC, Cho SC, Yoon DY, Lee HJ (2006) Association of the DAT1 polymorphism with attention deficit hyperactivity disorder (ADHD): a family-based approach. Am J Med Genet B 141B(3):309-311. https://doi.org/10.1002/ajmg.b.30282

Liu J, Yang A, Zhang Q, Yang G, Yang W, Lei H, Quan J, Qu F, Wang M, Zhang Z, Yu K (2015) Association between genetic variants in SLC25A12 and risk of autism spectrum disorders: an integrated meta-analysis. Am J Med Genet B Neuropsychiatr Genet 168B(4):236-246. https://doi.org/10.1002/ajmg.b.32304

Lopez-Leon S, Janssens AC, Gonzalez-Zuloeta Ladd AM, Del-Favero J, Claes SJ, Oostra BA, van Duijn CM (2008) Meta-analyses of genetic studies on major depressive disorder. Mol Psychiatry 13(8):772-785. https://doi.org/10.1038/sj.mp.4002088

Lunetta KL, Faraone SV, Biederman J, Laird NM (2000) Family-based tests of association and linkage that use unaffected sibs, covariates, and interactions. Am J Hum Genet 66(2):605-614. https:// doi.org/10.1086/302782

Maher BS, Marazita ML, Ferrell RE, Vanyukov MM (2002) Dopamine system genes and attention deficit hyperactivity disorder: a meta-analysis. Psychiatr Genet 12(4):207-215. https://doi. org/10.1097/00041444-200212000-00003

Markowitz JS, Patrick KS (2008) Differential pharmacokinetics and pharmacodynamics of methylphenidate enantiomers: does chirality matter? J Clin Psychopharmacol 28(3 Suppl 2):S54-S61. https://doi.org/10.1097/JCP.0b013e3181733560

Martinez-Levy G, Diaz-Galvis J, Briones-Velasco M, Gomez-Sanchez A, De la Pena-Olvera F, Sosa-Mora L, Palacios-Cruz L, RicardoGarcell J, Reyes-Zamorano E, Cruz-Fuentes C (2009) Genetic interaction analysis for DRD4 and DAT1 genes in a group of Mexican ADHD patients. Neurosci Lett 451(3):257-260. https ://doi.org/10.1016/j.neulet.2009.01.004

Martinez-Levy GA, Benjet C, Briones-Velasco M, Perez-Molina A, Nani A, Cruz-Fuentes CS (2013) Genetic variability of DRD4 and DAT1 in the urban population of Mexico City. Salud Ment 36(3):189-192. https://doi.org/10.17711/sm.0185-3325.2013.024 
Mazei-Robinson MS, Blakely RD (2006) ADHD and the dopamine transporter: are there reasons to pay attention? Handb Exp Pharmacol (175):373-415

McHugh PC, Buckley DA (2015) The structure and function of the dopamine transporter and its role in CNS diseases. Vitam Horm 98:339-369. https://doi.org/10.1016/bs.vh.2014.12.009

Melchers P, Preuss U (1994) K-ABC: Kaufman-asessment battery for children. Deutsche Bearbeitung. Swets\&Zeitglinger, Amsterdam

Mick E, Kim JW, Biederman J, Wozniak J, Wilens T, Spencer T, Smoller JW, Faraone SV (2008) Family based association study of pediatric bipolar disorder and the dopamine transporter gene (SLC6A3). Am J Med Genet B 147B(7):1182-1185. https://doi. org/10.1002/ajmg.b.30745

Mill J, Asherson P, Browes C, D'Souza U, Craig I (2002) Expression of the dopamine transporter gene is regulated by the $3^{\prime}$ UTR VNTR: evidence from brain and lymphocytes using quantitative RT-PCR. Am J Med Genet 114(8):975-979. https://doi. org/10.1002/ajmg.b.10948

Mill J, Asherson P, Craig I, D'Souza UM (2005) Transient expression analysis of allelic variants of a VNTR in the dopamine transporter gene (DAT1). BMC Genet 6:3. https://doi. org/10.1186/1471-2156-6-3

Miller GM, Madras BK (2002) Polymorphisms in the 3'-untranslated region of human and monkey dopamine transporter genes affect reporter gene expression. Mol Psychiatry 7(1):44-55. https://doi. org/10.1038/sj/mp/4000921

Morgan JE, Caplan B, Tung I, Norona AN, Baker BL, Lee SS (2018) COMT and DAT1 polymorphisms moderate the indirect effect of parenting behavior on youth ADHD symptoms through neurocognitive functioning. Child Neuropsychol 24(6):823-843. https ://doi.org/10.1080/09297049.2017.1346067

Niederhofer H, Menzel F, Gobel K, Hackenberg B, Richter R, Walter MH, Gross C, Huber M, Pycha R, Menzel HJ (2008) A preliminary report of the dopamine receptor $\mathrm{D}(4)$ and the dopamine transporter 1 gene polymorphism and its association with attention deficit hyperactivity disorder. Neuropsychiatr Dis Treat 4(4):701-705

Onnink AM, Franke B, van Hulzen K, Zwiers MP, Mostert JC, Schene AH, Heslenfeld DJ, Oosterlaan J, Hoekstra PJ, Hartman CA, Vasquez AA, Kan CC, Buitelaar J, Hoogman M (2016) Enlarged striatal volume in adults with ADHD carrying the 9-6 haplotype of the dopamine transporter gene DAT1. J Neural Transm (Vienna, Austria: 1996) 123(8):905-915. https://doi.org/10.1007/ s00702-016-1521-x

Ortega-Rojas J, Arboleda-Bustos CE, Morales L, Benitez BA, Beltran D, Izquierdo A, Arboleda H, Vasquez R (2017) Study of genetic variants in the BDNF, COMT, DAT1 and SERT genes in Colombian children with attention deficit disorder. Revista colombiana de psiquiatria 46(4):222-228. https://doi.org/10.1016/j. rcp.2016.08.006

Pinsonneault JK, Han DD, Burdick KE, Kataki M, Bertolino A, Malhotra AK, Gu HH, Sadee W (2011) Dopamine transporter gene variant affecting expression in human brain is associated with bipolar disorder. Neuropsychopharmacology 36(8):1644-1655. https://doi.org/10.1038/npp.2011.45

Polanczyk GV, Willcutt EG, Salum GA, Kieling C, Rohde LA (2014) ADHD prevalence estimates across three decades: an updated systematic review and meta-regression analysis. Int J Epidemiol 43(2):434-442. https://doi.org/10.1093/ije/dyt261

Politi C, Ciccacci C, Novelli G, Borgiani P (2018) Genetics and treatment response in Parkinson's disease: an update on pharmacogenetic studies. Neuromolecular Med 20(1):1-17. https://doi. org/10.1007/s12017-017-8473-7

Purcell S, Neale B, Todd-Brown K, Thomas L, Ferreira MA, Bender D, Maller J, Sklar P, de Bakker PI, Daly MJ, Sham PC (2007) PLINK: a tool set for whole-genome association and population-based linkage analyses. Am J Hum Genet 81(3):559_ 575. https://doi.org/10.1086/519795

Qian Q, Wang Y, Li J, Yang L, Wang B, Zhou R, Glatt SJ, Faraone SV (2007) Evaluation of potential gene-gene interactions for attention deficit hyperactivity disorder in the Han Chinese population. Am J Med Genet Part B Neuropsychiatr Genet 144b(2):200-206. https://doi.org/10.1002/ajmg.b.30422

Sambataro F, Podell JE, Murty VP, Das S, Kolachana B, Goldberg TE, Weinberger DR, Mattay VS (2015) A variable number of tandem repeats in the 3'-untranslated region of the dopamine transporter modulates striatal function during working memory updating across the adult age span. Eur J Neurosci 42(3):1912-1918. https ://doi.org/10.1111/ejn.12956

Sery O, Paclt I, Drtilkova I, Theiner P, Kopeckova M, Zvolsky P, Balcar VJ (2015) A 40-bp VNTR polymorphism in the 3'-untranslated region of DAT1/SLC6A3 is associated with ADHD but not with alcoholism. Behav Brain Funct 11:8. https://doi.org/10.1186/ s12993-015-0066-8

Shang CY, Gau SS (2014) Association between the DAT1 gene and spatial working memory in attention deficit hyperactivity disorder. Int J Neuropsychopharmacol 17(1):9-21. https://doi. org/10.1017/s1461145713000783

Simsek M, Al-Sharbati M, Al-Adawi S, Ganguly SS, Lawatia K (2005) Association of the risk allele of dopamine transporter gene (DAT1*10) in Omani male children with attention-deficit hyperactivity disorder. Clin Biochem 38(8):739-742. https://doi. org/10.1016/j.clinbiochem.2005.04.016

Smith KM, Daly M, Fischer M, Yiannoutsos CT, Bauer L, Barkley R, Navia BA (2003) Association of the dopamine beta hydroxylase gene with attention deficit hyperactivity disorder: genetic analysis of the Milwaukee longitudinal study. Am J Med Genet B 119B(1):77-85. https://doi.org/10.1002/ajmg.b.20005

Soleimani R, Salehi Z, Soltanipour S, Hasandokht T, Jalali MM (2018) SLC6A3 polymorphism and response to methylphenidate in children with ADHD: a systematic review and meta-analysis. Am J Med Genet B 177(3):287-300. https://doi.org/10.1002/ ajmg.b.32613

Stanley A, Chavda K, Subramanian A, Prabhu SV, Ashavaid TF (2017) DRD4 and DAT1 VNTR genotyping in children with attention deficit hyperactivity disorder. Indian J Clin Biochem 32(2):239242. https://doi.org/10.1007/s12291-016-0587-4

Swanson JM, Flodman P, Kennedy S, Spence MA, Moyzis R, Schuck S, Murias M, Moriarity J, Barr C, Smith M, Posner M (2000) Dopamine genes and ADHD. Neurosci Biobehav Rev 24(1):2125. https://doi.org/10.1016/s0149-7634(99)00062-7

Tarnok Z, Ronai Z, Gervai J, Kereszturi E, Gadoros J, Sasvari-Szekely M, Nemoda Z (2007) Dopaminergic candidate genes in Tourette syndrome: association between tic severity and $3^{\prime}$ UTR polymorphism of the dopamine transporter gene. Am J Med Genet Part B Neuropsychiatr Genet 144B(7):900-905. https://doi.org/10.1002/ ajmg.b.30517

Taylor S (2013) Molecular genetics of obsessive-compulsive disorder: a comprehensive meta-analysis of genetic association studies. Mol Psychiatry 18(7):799-805. https://doi.org/10.1038/mp.2012.76

Tellegen P, Winkel M, Laros J (2003) Snijders Oomen non-verbal intelligence test revised (SON-R). Hofgrefe-Verlag, Göttingen

Tewes U, Rossmann P, U S (1999) Der Hamburg-Wechsler-Intelligenztest für Kinder (HAWIK-III)-3. Auflage, 3rd edn. Huber-Verlag, Bern

Thomas R, Sanders S, Doust J, Beller E, Glasziou P (2015) Prevalence of attention-deficit/hyperactivity disorder: a systematic review and meta-analysis. Pediatrics 135(4):e994-e1001. https://doi. org/10.1542/peds.2014-3482

Todd RD, Jong YJ, Lobos EA, Reich W, Heath AC, Neuman RJ (2001) No association of the dopamine transporter gene $3^{\prime}$ VNTR 
polymorphism with ADHD subtypes in a population sample of twins. Am J Med Genet 105(8):745-748

Ujike H, Harano M, Inada T, Yamada M, Komiyama T, Sekine Y, Sora I, Iyo M, Katsu T, Nomura A, Nakata K, Ozaki N (2003) Nineor fewer repeat alleles in VNTR polymorphism of the dopamine transporter gene is a strong risk factor for prolonged methamphetamine psychosis. Pharmacogenomics J 3(4):242-247. https ://doi.org/10.1038/sj.tpj.6500189

VanNess SH, Owens MJ, Kilts CD (2005) The variable number of tandem repeats element in DAT1 regulates in vitro dopamine transporter density. BMC Genet 6:55. https://doi. org/10.1186/1471-2156-6-55

Waldman ID, Rowe DC, Abramowitz A, Kozel ST, Mohr JH, Sherman SL, Cleveland HH, Sanders ML, Card JHC, Stever C (1998) Association and linkage of the dopamine transporter gene and attention-deficit hyperactivity disorder in children: heterogeneity owing to diagnostic subtype and severity. Am J Hum Genet 63(6):1767-1776. https://doi.org/10.1086/302132

Wang Y, Wang Z, Yao K, Tanaka K, Yang Y, Shirakawa O, Maeda K (2008) Lack of association between the dopamine transporter gene $3^{\prime}$ VNTR polymorphism and attention deficit hyperactivity disorder in Chinese Han children: case-control and family-based studies. Kobe J Med Sci 53(6):327-333

Wechsler D (1991) Examiner's manual: Wechsler Intelligence Scale for children, 3rd edn. The Psychological Corporation, San Antonio

Weiss R (2006) Grundintelligenztest Skala 2-Revision (CFT 20-R) mit Wortschatztest und Zahlenfolgentest-Revision (Ws/ZF-R). Hofgrefe-Verlag, Göttingen

Wiers CE, Lohoff FW, Lee J, Muench C, Freeman C, Zehra A, Marenco S, Lipska BK, Auluck PK, Feng N, Sun H, Goldman D, Swanson JM, Wang GJ, Volkow ND (2018) Methylation of the dopamine transporter gene in blood is associated with striatal dopamine transporter availability in ADHD: a preliminary study. Eur $\mathbf{J}$ Neurosci 48(3):1884-1895. https://doi.org/10.1111/ejn.14067

Wiguna T, Ismail RI, Winarsih NS, Kaligis F, Hapsari A, Budiyanti L, Sekartini R, Rahayu S, Guerrero APS (2017) Dopamine transporter gene polymorphism in children with ADHD: a pilot study in Indonesian samples. Asian J Psychiatry 29:35-38. https://doi. org/10.1016/j.ajp.2017.03.041

Wohl M, Boni C, Asch M, Cortese S, Orejarena S, Mouren MC, Gorwood P, Purper-Ouakil D (2008) Lack of association of the dopamine transporter gene in a French ADHD sample. Am J Med Genet Part B Neuropsychiatr Genet 147b(8):1509-1510. https ://doi.org/10.1002/ajmg.b.30695

World Health Organization (2016) 10th international classification of diseases (ICD-10). WHO. http://www.who.int/classifications/icd/ icdonlineversions/en/. Accessed 24 Feb 2017

Yang BR, Chan RCK, Jing J, Li T, Sham P, Chen RYL (2007) A metaanalysis of association studies between the 10-repeat allele of a VNTR polymorphism in the 3'-UTR of dopamine transporter gene and attention deficit hyperactivity disorder. Am J Med Genet B 144B(4):541-550. https://doi.org/10.1002/ajmg.b.30453

Zhou Y, Michelhaugh SK, Schmidt CJ, Liu JS, Bannon MJ, Lin Z (2014) Ventral midbrain correlation between genetic variation and expression of the dopamine transporter gene in cocaineabusing versus non-abusing subjects. Addict Biol 19(1):122-131. https://doi.org/10.1111/j.1369-1600.2011.00391.x

Publisher's Note Springer Nature remains neutral with regard to jurisdictional claims in published maps and institutional affiliations. 